\title{
Long-term use of allopurinol in the treatment of gout
}

\author{
G. D. KERSLEY
}

Bath

Allopurinol (Zyloric) was first used in 1963 in the U.S.A. and in 1964 in England by Scott and his colleagues (Hall, Holloway, and Scott 1964; Scott, Hall, and Grahame, 1966) and by the author (Kersley, 1966a, b). The position in 1966 was reviewed together with the American literature by Rundles, Elion, and Hitchings (1966), who concluded that the xanthine oxidase inhibitor, allopurinol, was as effective in gout as the uricosuric agents. In very severe disease, or in cases with impaired renal function or urate stones, its use was of prime importance and often gave the best results in combination with colchicine. It was well tolerated when given in divided doses of up to $1 \mathrm{~g}$./day, but about 3 per cent. of patients developed skin reactions, predominantly pruritic and maculopapular. A few cases have also been reported of fever, malaise, jaundice, and mild leucopenia. Toxic reactions regressed within a few days of the drug being stopped.

\section{Present investigations}

The present paper reports data from observations on 54 patients with gout treated for up to $5 \frac{1}{2}$ years with allopurinol, and includes the latest information on the 38 cases reported by Kersley (1966).

That series included observations on seventeen patients treated consecutively with $\mathbf{4 0 0} \mathbf{~ m g}$. sulphinpyrazone (Anturan), when the average plasma uric acid (PUA) fell to $6.0 \mathrm{mg}$. per cent., $400 \mathrm{mg}$. sulphinpyrazone plus $400 \mathrm{mg}$. allopurinol (average PUA $3.7 \mathrm{mg}$. per cent.), and $400 \mathrm{mg}$. allopurinol alone (average PUA $4 \cdot 2 \mathrm{mg}$. per cent.). It also showed in eight cases that if allopurinol was stopped after a year's treatment, the PUA level gradually rose. During treatment the average PUA was $4 \mathrm{mg}$. per cent., one month later $6.5 \mathrm{mg}$. per cent., and 2 months later $7.5 \mathrm{mg}$. per cent. During the year's therapy there was minimal toxicity. A study of the effect of allopurinol on uric acid and oxypurine excretion was also included.

Of that original series of 38 patients, two have died of causes unassociated with the disease and two have ceased treatment because of a very marked improvement (after 3 years these two cases have not relapsed). The remaining 34 patients have required continuous therapy with allopurinol in order to control symptoms and maintain reasonable PUA levels, but all have been kept well by suitable allopurinol dosage except two who still require the addition of sulphinpyrazone to the regimen. Even these two, who were originally extremely ill and crippled, have continued to improve on this combined therapy.

The present series of 54 cases consists of 51 men and three women. They were all asked whether they knew of any gout in the family; 52 per cent. replied in the negative and 48 per cent. knew of a family history of the disease. Of those with a positive history, the average age at onset of symptoms was 37 , while the age at onset of the remainder averaged 47 years. All three women gave a positive family history of gout.

Toxicity was minimal; two had very slight rashes, not requiring alteration of treatment, and two had slight headaches if the dosage of allopurinol exceeded $300 \mathrm{mg}$. per day-one of these had serious renal damage. Five patients had had renal colic or gravel before treatment, but this trouble had ceased with use of the xanthine oxidase inhibitor. Although there was an initial tendency for allopurinol, like the uricosuric drugs, to stir up gouty attacks, this has been no serious problem since all patients were given as a routine daily colchicine for the first 6 weeks of therapy. As a precaution they were also issued with a 2-day supply of phenylbutazone in case of an acute attack; they were told in that event to take $800 \mathrm{mg}$. per day, but not to change the rest of their treatment. 
The length of time the 54 patients have been under treatment with allopurinol is shown in Fig. 1. The shortest duration of allopurinol therapy was over a year and the longest over $5 \frac{1}{2}$ years (mean 2 years 4 months).

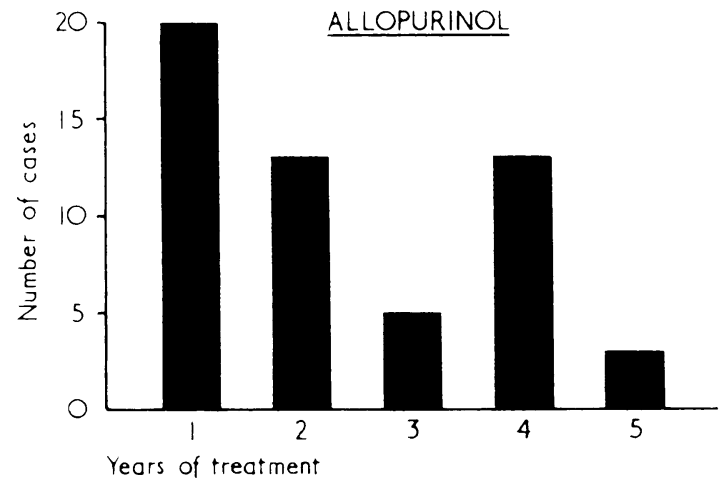

Fli. I Length of allopurinol treatment in years in 34 of the original series of 38 and 20 other patients.

The dosage on which they have been stabilized is given in Fig. 2. Satisfactory maintenance dosage varied from nil for the two in remission, $100 \mathrm{mg}$. (1). and $200 \mathrm{mg}$. (8), to two patients requiring $600 \mathrm{mg}$. per day and two needing the concomitant use of sulphinpyrazone. The majority, 29 cases, required 300 to $400 \mathrm{mg}$. to produce complete cessation of attacks and to reduce the urate level to a normal range.

Fig. 3 illustrates the effect of various dosages of drugs on PUA levels in six patients.

\section{Case reports}

Four cases are cited to illustrate other special points.

CASE 1 (The worst case in this series showing the value of allopurinol combined with anturan).

A man aged 55, who gave a history of gout in his grandfather. had his first attack at the age of 34 years. At the age of 41 he was put on prednisolone $10 \mathrm{mg}$., which he

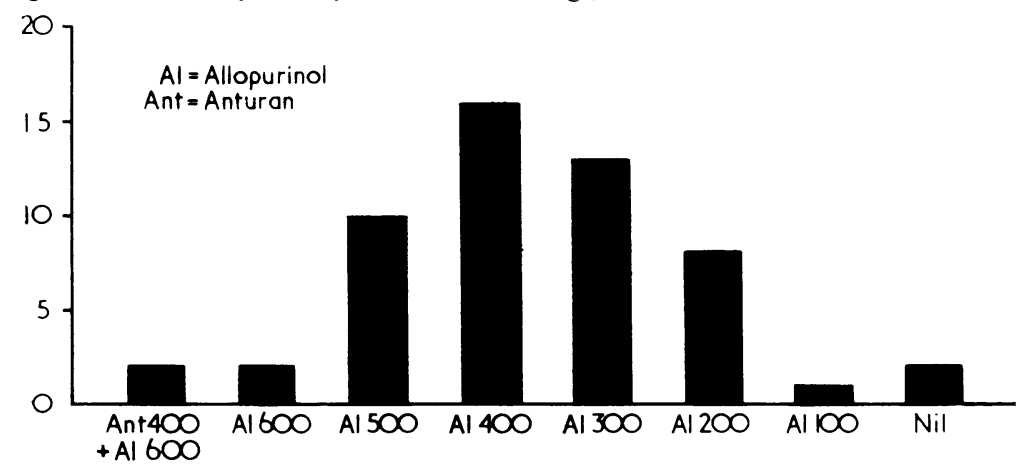

Ha. 2 Dosage on which 54 patients were stabilized.

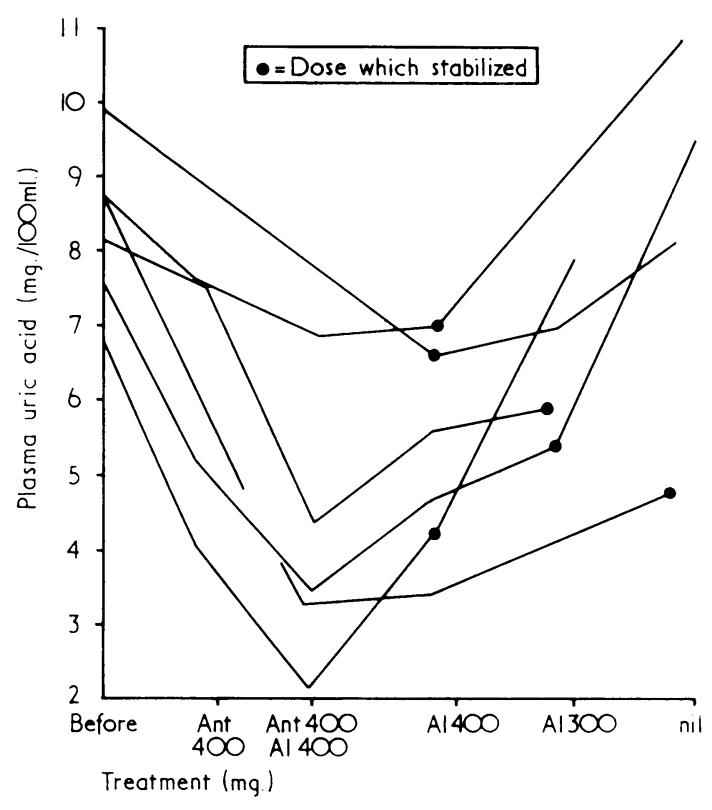

FIci. 3 Effects of various dosages of anturan (Ant) and allopurinol $(A l)$ on the plasma uric acid level in six different patients.

continued to take for 3 years as fulminant gout developed every time he reduced the dose. He then took probenecid $2 \mathrm{~g}$. day plus colchicine, and this made the attacks less acute, but his joints were becoming permanently swollen and by the age of 48 he was developing discharging tophi on the heels. The attacks became worse with worry or exercise.

The treatment was then changed to anturan $600 \mathrm{mg}$. day combined with colchicine, but this gave little benefit and the PUA was still $8 \mathrm{mg}$. per cent. At this period some tophi were removed surgically. Phenylbutazone $600 \mathrm{mg}$. day controlled the acute attacks better than indomethacin $100 \mathrm{mg}$., but in spite of this regimen he was rapidly becoming crippled; he could only rise from his chair with help because of pain in the knees and he could not wear shoes or boots.

In February, 1965, at the age of 51, he began to take allopurinol $400 \mathrm{mg}$. day plus anturan $600 \mathrm{mg}$. day and after a month the PUA had dropped to $4.6 \mathrm{mg}$. per cent. 
and he was able to wear shoes for the first time for a year. At the end of 8 months he was able to dance after a fashion. He is still on this regimen and has had no real attacks for over a year. The joints are less swollen and all the tophi healed and smaller.

CASE 2 (One of the two patients that have been able to discontinue all medication).

A man aged 72 had his first attack at the age of 61 . The PUA was on two occasions 8.9 and $10.4 \mathrm{mg}$. per cent.; on allopurinol $400 \mathrm{mg}$./day and anturan $600 \mathrm{mg}$./day, it came down to $3 \cdot 2 \mathrm{mg}$. per cent. and on allopurinol alone it remained at $3.4 \mathrm{mg}$. per cent. After 7 months this treatment was stopped and 2 years later the PUA was only $4.8 \mathrm{mg}$. per cent., the patient having had only one slight gouty attack in this period after a surgical operation.

CASE 3 (Renal disease with a calculus and gravel). A man aged 62, who gave a family history of gout, had his first attack at the age of 30 years. The PUA had been as high as $16 \mathrm{mg}$. Fer cent., and he was hypertensive with a blood urea level of $\mathbf{4 2} \mathrm{mg}$. per cent. There was a small calculus in the right renal pelvis. On anturan $\mathbf{4 0 0} \mathrm{mg}$./day, the PUA dropped to $6.1 \mathrm{mg}$. per cent. but he had repeated attacks of pain in the loins as well as haematuria and gravel. When allopurinol $\mathbf{4 0 0} \mathrm{mg}$./day was added, the PUA fell to $2 \cdot 3 \mathrm{mg}$. per cent. The attacks of haematuria and renal pain ceased and have not recurred in the last 2 years.

CASE 4 (Early gout).

A youth aged 17 developed attacks of pain and swelling in various joints after slight trauma at games. The PUA was found to be $8.6 \mathrm{mg}$. per cent. and the blood urea level $20 \mathrm{mg}$. per cent. On a dosage of allopurinol $400 \mathrm{mg}$. /day, the PUA steadily settled to 6.5 and then to $2.8 \mathrm{mg}$. per cent. After 4 months he is playing rugger and doing crosscountry running.

\section{Discussion}

The use of allopurinol was treated at first with extreme caution in view of possible long-term effects of interference with enzyme reactions, but no such ill-effects have come to light after 5 years. After an initial period of up to 6 weeks, during which regular colchicine administration is advisable, the gout nearly always comes under good control. In a few very severe cases anturan should be used at the same time. Phenylbutazone can be used for an occasional acute attack. The dose which can be as high as $\mathbf{8 0 0}$ $\mathrm{mg}$./day should be gradually decreased, but the majority of patients require a maintenance dose of 400 to $300 \mathrm{mg}$./day. Toxicity is minimal and there is no evidence of loss of effectiveness after 5 years of administration.

As the use of allopurinol may well be required for life the question arises when it should be started. Obviously, when there are frequent attacks of gout and tophi are forming, there can be no argument. There may well be a case for its use to protect the kidneys when there is a constantly raised PUA and certainly when gravel or a renal calculus is present. When there is only an occasional attack of gout and the PUA is spasmodically only a little raised, a watching brief may be preferable to persuading the patient to undertake indefinite medication. We still come back to the old saying that the success of antigout treatment depends on the doctor-patient relationship engendered by proper explanation of his disease to the patient.

\section{Summary}

Observations have been made on 54 cases of gout under treatment with allopurinol for from 1 to $5 \frac{1}{2}$ years. In all cases the gout was completely controlled, and two patients were able to cease treatment. 70 per cent. were satisfactorily stabilized on a daily dosage of 300 to $400 \mathrm{mg}$. or less. Two required anturan with the allopurinol to produce complete relief. In five cases with previous symptoms of renal colic or gravel, these symptoms ceased. Toxicity was minimal and in no case did the allopurinol have to be withdrawn. There was no tendency to reduction of effect after prolonged continuous treatment.

\section{References}

Hall, A. P., Holloway, V. P., And Scott, J. T. (1964) Ann. rheum. Dis., 23, 439 (4-Hydroxypyrazolo (3,4-d) pyrimidine (HPP) in the treatment of gout).

KeRSLEY, G. D. (1966a) Ibid., 25, 353 (Treatment of gout by reduction of uric acid production).

- (1966b) Ibid., 25, 643 (Allopurinol in primary go:t with and after the administration of uricosuric agents).

Rundles, R. W., Elion, G. B., ANd Hitchings, G. H. (1966) Bull. rheum. Dis., 16, No. 6, p. 400 (Allopurinol in the treatment of gout and secondary hyperuricemia).

Scott, J. T., Hall, A. P.; ANd Grahame, R. (1966) Brit. med. J., 2, 321 (Allopurinol in treatment of gout). 


\section{RÉSUMÉ}

L'emploi à long terme de l'allopurinol dans le traitement de la goutte

Des observations ont été faites à propos de 54 cas de goutte sous traitement avec l'allopurinol pendant un an à $5 \frac{1}{2}$ ans. Dans tous les cas la goutte a été combattue avec succès et deux malades ont pu cesser le traitement. 70 pour cent ont été stabilisés d'une façon satisfaisante en prenant une dose journalière de 300 à $400 \mathrm{mg}$. ou moins. Deux ont eu besoin d'anturan avec l'allopurinol afin de produire un soulagement complet. Dans cinq cas avec des symptômes antérieurs de colique rénale ou de gravelle ces symptômes ont disparu. La toxicité était minime et dans aucun des cas on a eu à cesser le traitement avec l'allopurinol. Il n'y a eu aucune tendance à la réduction de son effet après un traitement long et continu.

\section{SUMARIO}

Empleo de alopurinol, a largo plazo, en el tratamiento de gota

Se han realizado observaciones en 54 casos de gota bajo tratamiento con alopurinol, por periodos de entre uno y cinco años y medio. En todos los casos, la gota pudo ser controlada por completo, y dos pacientes estuvieron en condiciones de cesar el tratamiento. El 70 por ciento fue estabilizado satisfactoriamente en una dosis diaria de 300 a 400 mg., o menos. Dos requirieron anturan con alopurinol para producir alivio completo. En cinco casos con síntomas previos de cólico o cálculos renales, estos sintomas cesaron. La toxicidad fue mínima y en ningún caso tuvo que suspenderse el alopurinol. No se observó tendencia a la reducción del efecto al cabo de tratamiento prolongado continuo. 